УДК 004.774.6

Олексюк Василь Петрович, доцент кафедри інформатики та методики їі викладання ТНПУ імені Володимира Гнатюка, м. Тернопіль, e-mail: oleksyuk@fizmat.tnpu.edu.ua

Олексюк Олеся Романівна, аспірантка Інституту інформаційних технологій і засобів навчання НАПН України, м. Київ, e-mail: oolessia@gmail.com

\title{
ІНСТИТУЦЙНИЙ РЕПОЗИТАРІЙ: МОЖЛИВОСТІ ЗАСТОСУВАННЯ У НАВЧАЛЬНОМУ ПРОЦЕСІ
}

\begin{abstract}
Анотація
У статті на основі аналізу довідкової і наукової літератури розглянуто понятійний апарат, пов'язаний з електронними бібліотеками. Розглянуто особливості вживання у сучасних дослідженнях поняття «інституційний репозитарій». Визначено аспекти застосування інституційного репозитарію у ВНЗ (як сховища наукових i навчальних матеріалів, як засобу їх поширення у корпоративній мережі та Інтернеті, як засобу організації діяльності студентів, як об’єкта вивчення). Розроблено структуру фондів і колекцій інституційного репозитарію фізико-математичного факультету Тернопільського національного педагогічного університету імені Володимира Гнатюка. Описано досвід упровадження в навчальний процес системи DSpace.

Ключові слова: навчання, майбутній учитель інформатики, інституційний репозитарій, система DSpace.

Постановка проблеми. Сучасний етап розвитку науки й освіти України можна охарактеризувати активним створенням і впровадженням цифрових сховищ і архівів. Значна кількість вищих навчальних закладів (ВНЗ) і науково-дослідних установ реалізують концепцію відкритого доступу до результатів наукових досліджень через реалізацію моделі так званого інституційного репозитарію. Для освітян і науковців цікавим $є$ підхід, за яким існує можливість доступу до малотиражних видань. Зазвичай, такі матеріали залишаються мало поміченими, оскільки їх публікують у кількох паперових екземплярах або на мережних сервісах, які мають персоніфікований доступ, обмежений користувачами корпоративної мережі ВНЗ.
\end{abstract}


Аналіз досліджень і публікацій. Аналізу функціональних можливостей деяких систем електронних бібліотек присвячені роботи дослідників В. А. Резніченка, Г. Ю. Проскудіної, К. О. Кудима, О.В.Новицького та інших. Окремі аспекти впровадження електронних архівів у навчальних і наукових установах розглянуто у роботах О. Г. Кузьміної, Д. О. Тарасова, А. І. Андрухіва, О. М. Бруй. Проектуванню системи електронних бібліотек наукових i навчальних закладів присвячені дослідження О. М. Спіріна, С. М. Іванової. Теоретичні аспекти використання комп'ютерно-орієнтовананих засобів навчання досліджені у працях В. Ю. Бикова, М. І. Жалдака, Н. В. Морзе, С. А. Ракова, Ю. С. Рамського, Ю. В. Триуса та інших.

Метою статті є аналіз поняття «інституційний репозитарій», розгляд основних вимог до його функціональності. У статті буде описано досвід упровадження в навчальний процес системи DSpace, як платформи, на якій реалізовано інституційний репозитарій фізико-математичного факультету Тернопільського національного педагогічного університету імені Володимира Гнатюка.

Виклад основного матеріалу. Коротко розглянемо походження і розвиток поняття «інституційний репозитарій». Часто цей термін вживають як синонім понять «електронна бібліотека», «електронний архів».

Результати аналізу наукових джерел свідчать про те, що поняття «електронна бібліотека» у сучасних дослідженнях надзвичайно багатогранне і не отримало належного наукового осмислення на енциклопедичному рівні. На основі аналізу джерел $[5 ; 8 ; 10]$, ми опиралися на таке трактування: «електронна бібліотека розподілена інформаційна система, що дозволяє накопичувати, надійно зберігати й ефективно використовувати різноманітні колекції електронних повнотекстових документів, які доступні в зручному для користувача вигляді через глобальні мережі передавання даних» [9].

Як синонім поняття «електронна бібліотека» застосовують поняття «електронний архів», який набув ужитку з розвитком руху відкритого доступу (Open Access). У цьому випадку під поняттям «електронний архів» розуміють сайт, що містить впорядковані наукові матеріали у відкритому доступі [1]. Проте, на нашу думку, поняття «електронний архів» має дещо двобічний характер і його більш доцільно використовувати для оцифрованих архівних матеріалів. 
Поряд із поняттям «електронний архів» вживають терміни «інституційний репозитарій (репозиторій)». Проаналізуємо їх зміст.

Термін «репозиторій» широко використовують у комп’ютерних науках. У цьому контексті він означає будь-яку систематизовану базу даних, організоване місце зберігання програмних продуктів, які доступні для подальшого розповсюдження в мережі. Наприклад, у програмуванні для організації спільної роботи над програмою використовують «репозиторії-каталоги», до яких користувач має змогу завантажити необхідні програми, або «репозиторії-портали», які поєднують функції каталогу i засобу організації команд для розробки програмного забезпечення. Сучасні операційні системи (OC) (FreeBSD, OpenSolaris, більшість дистрибутивів OC Linux) використовують «репозиторії пакетів», до яких звертаються у процесі встановлення програмного забезпечення.

Протягом останніх років термін активно використовується в бібліотечній галузі. У термінологічному словнику [12, с. 255] наведено переклад терміну «repository» i тлумачення його як сховище архівних матеріалів, рукописів книжок та ін. Рекомендується його використання як синонім слова «депозитарій».

Щодо написання «репозитарій» чи «репозитарій», цікавою $є$ думка М. В Стрішнець, яка рекомендує надати перевагу першому варіанту, пояснюючи це аналогією з іншим запозиченням, яке давно прижилося - «депозитарій». Між тим у літературі також зустрічаємо вживання літери «о» (depository), як і в англійському слові-прототипі «repository» [13].

Щодо вживання термінів «інституційний» чи «інституціональний», то, на нашу думку, доцільно вживати перший [2, с.507], оскільки репозитарій є утворенням певної установи, а під терміном «інституція» власне і розуміють установу або заклад [7, c. 192].

Очевидно, понятійний апарат понять, пов’язаних з електронними бібліотеками, розвиватиметься й надалі.

Серед великої кількості визначень поняття «інституційний репозитарій» розглянемо такі:

- $\quad$ набір послуг (сервісів), які університет пропонує власним співробітникам для управління і розповсюдження наукових матеріалів у електронній формі [16]; 
- база даних наукових матеріалів в Інтернеті, що належать окремій організації (на противагу тематичним репозитаріям) [15].

На нашу думку, зазначене поняття $є$ поєднанням цих двох підходів: «інституційний репозитарій»—- мережний сервіс зі зберігання, накопичення, систематизації та поширення творів у цифровому форматі, який надає науковоосвітня установа своїм працівникам та іншим зацікавленим особам.

Відповідно зібрані, впорядковані інституційні репозитарії зберігають інтелектуальний продукт установи і є важливою складовою наукової комунікації, яка:

- розширює доступ до наукових досліджень;

- сприяє контролю над науковими знаннями за допомогою академічної спільноти,

- збільшує конкуренцію і скорочує монопольну владу наукових журналів;

- виконує роль індикатора якості функціонування університету;

- демонструє наукове, громадське та економічне значення дослідницької діяльності [16].

Багато дослідників вказують, що інституційний репозитарій $є$ засобом збереження і накопичення матеріалів дослідницької діяльності науковців [10].

На нашу думку, можливості застосування інституційних репозитаріїв не мають обмежуватися лише сферою наукової діяльності викладачів й окремих студентів. Ми вважаємо, що застосування електронних архівів у педагогічному ВНЗ повинно мати систематичний і неперервний характер і здійснюватися упродовж усього терміну навчання студента.

У вищому педагогічному навчальному закладі вбачаємо такі можливості застосування інституційного репозитарію:

- як сховище наукових і навчальних матеріалів;

- як засіб їх поширення у корпоративній мережі та Інтернеті;

- як засіб організації навчально-пізнавальної і науково-дослідницької діяльності студентів;

-

Останній аспект набуває особливої ваги у випадку підготовки майбутнього вчителя інформатики, оскільки він зможе фахово зрозуміти і використати можливості інституційного репозитарію. 
Використовуючи інституційний репозитарій на кожному з етапів підготовки, студенти отримують вільний доступ до інституційного репозитарію, що дає їм можливість використовувати актуальну навчально-методичну документацію i відкриті матеріали досліджень інших студентів і викладачів. 3 іншого боку, студент, виконуючи дослідження, може використовувати систему й поповнювати репозитарій власними матеріалами.

Для визначення можливостей застосування інституційних репозитаріїв доцільним вважаємо проаналізувати зміст підготовки майбутнього вчителя інформатики й визначити основні результати його навчально-пізнавальної і науководослідницької діяльності. Такий підхід надасть можливість окреслити перелік матеріалів, які міститиме електронний архів, а також спроектувати його структуру.

Зазвичай, підготовка вчителя інформатики у вищих педагогічних навчальних закладах здійснюється за напрямом «Інформатика» (галузь знань: «Системні науки та кібернетика»), а також за напрямом підготовки «Математика» i «Фізика» (галузь знань «Фізико-математичні науки»).

Незважаючи та те, що навчальні плани цих спеціальностей у різних ВНЗ можуть відрізнятися, існують дисципліни (так звані «класичні»), які обов’язково присутні у кожному з них. Зосередимо увагу на циклі професійної і практичної підготовки майбутнього вчителя інформатики і розглянемо результати навчальнопізнавальної і науково-дослідницької діяльності з точки зору їх подання у формі матеріалів інституційного репозитарію.

Основним видом організації навчального процесу у ВНЗ є лекційні, лабораторні та практичні заняття. У випадку конспектування лекції за допомогою сучасних засобів ІКТ відповідний матеріал може бути доданий до особистої колекції студента. Більш природньою $є$ публікація викладачем електронних версій теоретичного матеріалу і навіть відеофрагментів лекційного заняття.

Можна передбачити, що такий підхід викликатиме заперечення у викладачів, які пов’язані з дотриманням їх авторських прав, а також із застосуванням у багатьох ВНЗ систем електронних курсів, які вже містять матеріали лекцій, лабораторних та практичних занять. Слід зазначити, що відкритий доступ до навчальних і наукових матеріалів у сучасному глобальному світі $є$ запорукою розвитку науки й освіти, іiі інтеграції у світові академічні спільноти [14]. Тому в усіх учасників навчального 
процесу слід формувати переконання важливості надання відкритого доступу до власних навчальних i наукових розробок. Такі погляди не мають суперечити світогляду особистості, а процес «самоархівування»у жодному випадку не має бути примусовим. Стосовно застосування систем електронних навчальних курсів, слід зазначити, що персоніфікований доступ до них обмежує можливості роботи 3 матеріалами після завершення вивчення або викладання дисципліни, що, зазвичай, призводить до їх обмеженого застосування.

Лабораторні і практичні заняття — це форми організації навчального процесу, використання яких надає можливість студентам одержати навички застосування теорії для розв'язання практичних задач, опанувати методи розв’язування цих задач. Формою подання результатів лабораторної або практичної роботи може бути звіт щодо іï виконання. Такий підхід у поєднанні з оцінюванням навчальних досягнень студента досить часто практикують у системах електронних курсів. На нашу думку, використання репозитаріїв для збереження звітів лабораторних робіт $\epsilon$ недоцільним, оскільки їх матеріал є комплексом вправ для формування навичок і значною мірою не ілюструє самостійну навчально-пізнавальну діяльність студента.

Важливою формою організації навчального процесу є індивідуальна робота студентів, оскільки вона передбачає створення умов для якнайповнішої реалізації їх творчих можливостей. У зв'язку з цим у навчальних програмах практично всіх дисциплін циклу професійної i практичної підготовки майбутнього вчителя інформатики передбачено індивідуальні навчально-дослідні завдання (ІНДЗ). Виконання зазначених завдань передбачає самостійне вивчення частини програмного матеріалу, систематизацію, поглиблення, узагальнення, закріплення та практичне застосування знань 3 навчального курсу і розвиток навичок самостійної роботи. Публікування в інституційному репозитарії текстів ІНДЗ, а також звітів про їх виконання сприятиме:

- формулюванню критеріїв якісного виконання навчально-дослідницьких завдань;

- розвитку навичок критичного оцінювання ІНДЗ;

- підвищенню якості робіт завдяки їх розміщенню у відкритому доступі;

- забезпеченню доступу до матеріалів;

- розвитку навичок оформлення результатів розв’язання задач; 
- формуванню навичок «самоархівування» результатів власної діяльності;

- унеможливленню їх копіювання з метою плагіату.

У випадку публікування ІНДЗ у інституційному репозитарії слід звернути увагу викладачів на необхідність систематичного поновлення їх тематики.

Важливою складовою навчання майбутнього вчителя інформатики $є$ його практична підготовка, яка, зазвичай, здійснюється у межах комп'ютерної, педагогічної та виробничої практик. Після їх завершення зібрані матеріали (конспекти уроків, щоденники, анкетування, фото, презентації, характеристики, відеофрагменти тощо) і написаний звіт можна зберігати у інституційному репозитарії.

У процесі науково-дослідницької роботи, студенти виконують реферати, курсові, дипломні (магістерські) роботи, а також можуть готувати наукові статті, матеріали до виступів на семінарах і конференціях.

Виконання курсової роботи має на меті формувати у майбутнього вчителя інформатики навички формулювання проблеми дослідження, розробки математичних моделей, проектування алгоритмів, упровадження засобів IКТ в освітній процес загальноосвітнього навчального закладу, розвинути у них навички творчої самостійної роботи, а також поглибити рівень вивчення певних питань або тем.

Кваліфікаційна (дипломна, магістерська) робота має узагальнюючий характер, оскільки $є$ своєрідним підсумком підготовки фахівця. Вона $\epsilon$ самостійним оригінальним науковим дослідженням студента, у процесі якого він сам упорядковує накопичені наукові факти та доводить їх наукову цінність або практичну значимість.

Необхідність і доцільність публікування повнотекстових кваліфікаційних робіт в інституційних репозитаріях $є$ суперечливим питанням. Розв’язання зазначеної проблеми можливе у психологічному і технологічному аспектах.

Не викликає заперечень твердження, що застосування інституційних репозитаріїв має здійснюватися відповідно до загальновідомих дидактичних принципів: науковості, наочності, систематичності та послідовності, активності, індивідуалізації, доступності, всебічного розвитку особистості, цілісності, природовідповідності, взаємозв'язку навчання i розвитку, мотиваційного забезпечення навчального процесу, співробітництва [3]. О. М. Спірін, конкретизуючи вимоги до навчального процесу, організованого з використанням ІКТ, формулює важливий дидактичний принцип актуальності знань і професійних умінь, що 
характеризує навчальну діяльність студентів як систему, орієнтовану на новітні наукові досягнення, актуальні й перспективні потреби ринку праці щодо рівня кваліфікації фахівців, передбачає забезпечення педагогічних умов організації навчання i неперервного підвищення кваліфікації протягом життя [11, с. 68]. Інституційний репозитарій надає можливість відкритого доступу до новітніх результатів наукових досліджень i постійного безперешкодного оновлення навчальних матеріалів. Результати науково-дослідницької роботи викладачів (наукові публікації; звіти; матеріали конференцій; робочі навчальні програми; програми комп’ютерної, педагогічної і виробничої практик; патенти; авторські свідоцтва; підручники, навчальні посібники; збірники; конспекти лекцій 3 дисципліни; інструктивно-методичні матеріали до семінарських, практичних i лабораторних занять; методичні рекомендації і розробки викладача; мультимедійні презентації; програмні розробки викладача; фото, аудіо- і відеоматеріали тощо) можна зберегти у інституційному репозитарії.

Аналізуючи діяльність у системі освіти, окрім інформаційного простору навчальної i наукової діяльності, виділяють єдиний інформаційний простір управлінської діяльності [4, с. 35]. Тому в інституційному репозитарії доцільно створювати колекції адміністративних документів. На важливості забезпечення актуальними нормативними документи професійної діяльності викладача ВНЗ наголошує М.В.Кісіль: «..щоб викладач ВНЗ добре володів актуальними нормативними документи Міністерства освіти i науки України, отримував кваліфіковану допомогу з питань розробки робочих навчальних планів і особливостей оцінювання знань студентів в умовах кредитно-модульної системи навчання» [6]. У зв’язку з цим в інституційному репозитарії доцільно створити колекцію, яка містила, крім вищезгаданих, і нормативно-правові документи навчального закладу.

Враховуючи вищенаведені аспекти, пропонуємо структуру фондів і колекцій інституційного депозитарію (рис. 1). 


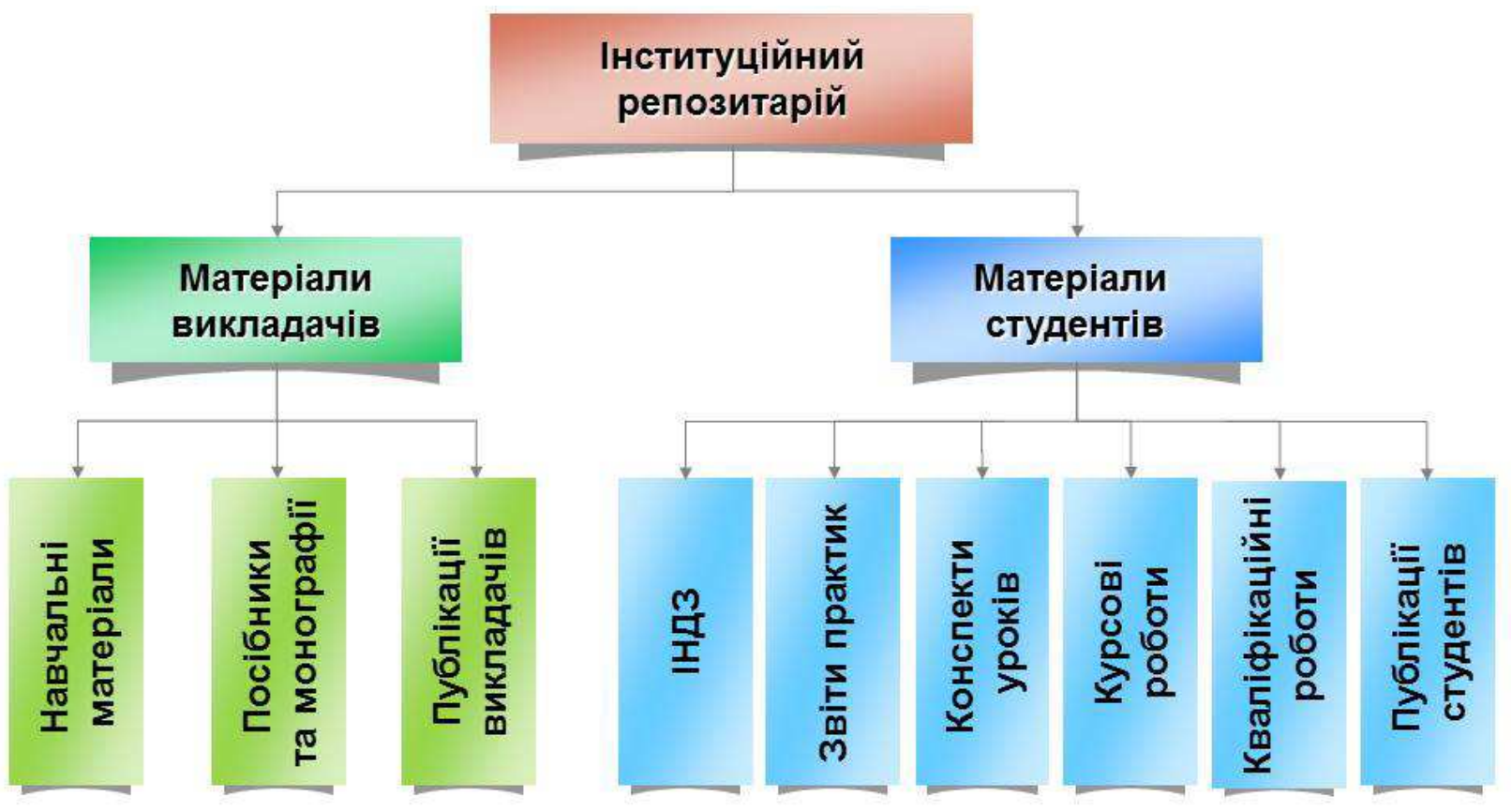

Рuc. 1. Структура фондів і колекцій освітнього інституційного репозитарію

Пропонована структура була реалізована в інституційному репозитарії фізикоматематичного факультету Тернопільського національного університету імені Володимира Гнатюка. Для створення згаданого репозитарію була використана відома система DSpace. Серед iï переваг виділимо безкоштовність, кросплатформенність, підтримку стандартизованого формату метаданих (Дублінське ядро), можливість обміну метаданими за пропоколом OAI, індексування матеріалів популярними пошуковими системами тощо. Важливою характеристикою системи DSpace $є$ iï можливість виконувати автентифікацію користувачів на основі стандартизованих протоколів і баз даних. Зокрема нами було здійснено інтеграцію інституційного репозитарію із сервісами навчального мережного комплексу факультету (вебпорталом, системою електронних курсів, електронною поштою, соціальною мережею, вікіпедією, відеохостингом). Для розв'язання такого завдання була використана єдина база облікових записів користувачів - LDAP каталог. Описаний підхід реалізує парадигму «фізматівець назавжди», яка передбачає одноразове надання студенту єдиних даних для авторизації. Тобто свій логін i пароль для доступу до факультетських ресурсів кожен фізматівець зможе використовувати не лише впродовж навчання в університеті, а й у подальшій професійній діяльності.

Інституційний репозитарій органічно доповнює сервіси мережного комплексу. Наповнюючи репозитарій протягом навчання власними матеріалами, студент формує 
власне портфоліо, яке репрезентуватиме його як педагога, науковця, програміста, фахівця в галузі інформаційних технологій.

Перспективи подальших досліджень вбачаємо у розробці методичних рекомендацій застосування системи DSpace у процесі навчання окремих дисциплін, дослідження мотиваційних аспектів публікації результатів науково-дослідницької діяльності у відкритому доступі, інтеграції ресурсів інституційних репозитаріїв та інших комп'ютерно-орієнтованих засобів навчання.

\section{Список використаних джерел}

1. Будапештська ініціатива відкритого доступу (BOAI) [Електронний ресурс]. — Режим доступу : http://www.soros.org/openaccess/translations/russian-translation. Заголовок з екрана.

2. Великий тлумачний словник сучасної української мови: 250000 слів і словосполучень / [авт. проекту та гол. ред. В. Т. Бусел]. - К. ; Ірпінь : Перун, 2005. $-1728 \mathrm{c}$.

3. Жалдак M. I. Комп’ютерно-орієнтовані засоби навчання математики, фізики, інформатики / М. І. Жалдак, В.В.Лапінський, М. І. Шут // Інформатика. 2004. — № 41 (281)

4. Засоби інформаційно-комунікаційних технологій єдиного інформаційного простору системи освіти України : колективна монографія / [В. В.Лапінський, А. Ю. Пилипчук, М. П. Шишкіна та ін. ; за ред. В. Ю. Бикова]. - К. : Пед. думка, 2010. $-160 \mathrm{c}$.

5. Земсков A. И. Электронная информация и электронные ресурсы : публикации и документы, фонды и библиотеки : учеб. пособие / А. И. Земсков, Я. Л. Штрайберг. - М. : ФАИР, 2007. - 528 с.

6. Кісіль М. В. Інформаційне забезпечення професійної діяльності викладача ВН3 / М. В. Кісіль // Науковий часопис НПУ імені М. П. Драгоманова. Сер. № 7. Релігієзнавство. Культурологія. Філософія : [зб. наук. праць] / редкол.: В. П. Андрущенко, Т. І. Андрущенко, С. В. Більченко [та ін.]. - К. : НПУ ім. М. П. Драгоманова, 2010. - Вип. 25 (38). - С. 50-53.

7. Новий тлумачний словник української мови: 42000 слів : для студ. вищ. та серед. навч. закл. : У 4 т. Т. 1 . А - С / уклад.: В. В. Яременко, О. М. Сліпушко ; наук. ред. Л. І. Андрієвський. - К. : Аконіт, 2001. - 911 с. - (Нові словники). 
8. Прилуцька Н. С. Особливості функціонування наукових і освітніх електронних бібліотек [Електронний ресурс] / Н. С. Прилуцька // Інформаційні технологіï i засоби навчання. - 2011. - № 2(22). - Режим доступу : http://journal.iitta.gov.ua/index.php/itlt/article/view/427/390.

9. Cпірін O. M. Проект концепції електронної бібліотеки Національної академії педагогічних наук України [Електронний ресурс] / О. М. Спірін, С. М. Іванова, О. В. Новицький, М. А. Шиненко // Інформаційні технології і засоби навчання. - 2010 - - № 6(20). - Режим доступу : http://journal.iitta.gov.ua/index.php/itlt/article/view/396/347. - Заголовок з екрана.

10. Спірін O.M. Проектування системи електронних бібліотек наукових і навчальних закладів АПН України [Електронний ресурс] / О. М. Спірін, В. М. Саух, В. А. Резніченко, О.В.Новицький // Інформаційні технології і засоби навчання. -

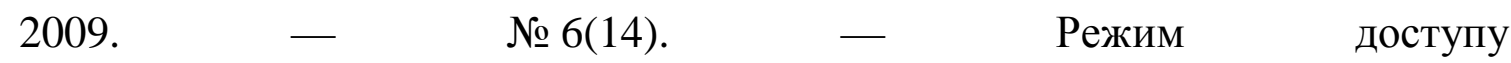
http://journal.iitta.gov.ua/index.php/itlt/article/view/213/199. - Заголовок з екрана.

11. Спірін O.M. Теоретичні та методичні засади професійної підготовки майбутніх учителів інформатики за кредитно-модульною системою: монографія [Електронний ресурс] / за наук. ред. акад. М. І. Жалдака. - Житомир : Вид-во ЖДУ iм. I. Франка, 2007. - 300 с. — Режим доступу : http://lib.iitta.gov.ua/id/eprint/459.

12. Стріменець H. B. English-Ukrainian Glossary of Library and Information Science : Англо-український словник-довідник бібліотечно-інформаційної термінології : А-Z / Н. В. Стрішенець. - К. : Нац. б-ка України ім. В. І. Вернадського, 2004. -329 c.

13. Стрішенець H. B. Наукова комунікація як елемент управління фондом [Електронний ресурс] / Н. В. Стрішенець // Бібліотекознавство. Документознавство. Інформологія. - $2009 . \quad$ - №3. - Режим доступу : http://www.nbuv.gov.ua/Portal/soc_gum/bdil/2009-3/7.pdf.

14. Університетські бібліотеки України підтримують Відкритий Доступ до Знань : Заява Міжнародної науково-практичної конференції [Електронний ресурс] // Діяльність бібліотек вищих навчальних закладів у світлі модернізації вищої освіти: Матеріали міжнар. наук.-практ. конф. (м. Севастополь, 19-21 травня 2009 р.). Севастополь : Вид-во СевНТУ, 2009. - 192 с. - Режим доступу : 
http://ula.org.ua/fileadmin/uba_documents/others_documents/Universitetski_biblioteki_Ukr ajini_pidtrimujut_Vidkritii_Dostup_do_Znan.pdf.

15. Crow R. The Case for Institutional Repositories: A SPARC Position Paper [Electronic resource] / R. Crow. - Washington : The Scholarly Publishing and Academic Resources Coalition, 2002. - 37 c. - Mode of access: http://www.arl.org/sparc/bm doc/ir_final_release_102-2.pdf.

16. Lynch C. Institutional Repositories: Essential infrastructure for scholarship in the digital age [Electronic resource] / Clifford A. Lynch // ARL. — 2003. - 226 (February 2003). — Mode of access : http://www.arl.org/resources/pubs/br/br226/br226ir.shtml.

\section{ИНСТИТУЦИОННЫЙ РЕПОЗИТАРИЙ: ВОЗМОЖНОСТИ ПРИМЕНЕНИЯ В УЧЕБНОМ ПРОЦЕССЕ}

Олексюк Василий Петрович, доцент кафедры информатики и методики ее преподавания ТНПУ имени Владимира Гнатюка, г. Тернополь, e-mail: oleksyuk@fizmat.tnpu.edu.ua

Олексюк Олеся Романовна, аспирант Института информационных технологий и средств обучения НАПН Украины, г. Киев, e-mail: oolessia@gmail.com

\section{Аннотация}

В статье на основе анализа справочной и научной литературы рассмотрены понятийный аппарат, связанный с электронными библиотеками, в частности проанализировано понятие «институциональный репозитарий». Определены аспекты применения институционального репозитария в вузе (как хранилища научных и учебных материалов, как средства их распространения в корпоративной сети и Интернете, как средства организации деятельности студентов, как объекта изучения). Проанализированы основные результаты учебной и научной деятельности будущего учителя информатики. Разработана структура фондов и коллекций институционного репозитария физико-математического факультета Тернопольского национального педагогического университета имени Владимира Гнатюка. Описан опыт внедрения в учебный процесс системы DSpace.

Ключевые слова: обучение, будущий учитель информатики, институциональный репозитарий, система DSpace. 


\section{INSTITUTIONAL REPOSITORY: EMPLOYMENT IN EDUCATION}

Vasyl' P. Oleksyuk, Associate Professor of the Department of Informatics and methods of it's teaching, Ternopil V. Hnatyuk National Pedagogical University, Ternopil, e-mail: oleksyuk@fizmat.tnpu.edu.ua

Olesya R. Oleksyuk, PhD student of the Institute of Information Technologies and Learning Tools of NAPS of Ukraine, Kyiv, e-mail: oolessia@gmail.com

\section{Resume}

The article investigated the concept of «institutional repository» and determined the aspects of institutional repositories in higher education. Institutional Repositories are information systems that allow preserving, storing and disseminating scientific knowledge produced in higher education and scientific research institutions. This study presented the main aspects using institutional repositories in educational process (such as storage of scientific and educational information, means of organization activity of students, object of studying). This article produced the structure of communities and collections of the institutional. It is described the experience of implementing of DSpace in the learning process.

Keywords: learning, institutional repository, DSpace. 